\title{
Analysis on the Causes and Countermeasures of Small and Medium-sized Enterprises' Business Risks in China's Commercial Banks
}

\author{
Mian Liu ${ }^{1, \text { a }}$ \\ 1Business School of Hohai University, Jiangsu, Nanjing, China, 211100
}

Keywords: Commercial Bank, Small and Medium-sized Enterprises, Business Risks

\begin{abstract}
With the continuous deepening of market economic reform, small and medium-sized enterprises in China have become an indispensable part of the national economy, and its risk characteristics make it less able to withstand risks. For banks, the ability of risk management plays a crucial role. The information asymmetry, private lending and the instability of the domestic and foreign economic environment all contribute to the credit risk problem of small and medium-sized enterprises in China. This paper, from the perspective of commercial banks, analyzes and summarizes the causes of business risk of small and medium-sized enterprises in China's commercial banks, does research on the existing situation and problems, and puts forward suggestions and countermeasures.
\end{abstract}

\section{Introduction of Credit Risk of Small and Medium-sized Enterprises in China}

The role of small and medium enterprises in market economy. Small and medium-sized enterprises are indispensable parts of China's national economy, which largely promote the social and economic development of our country. They are not only the inherent results of economic development but they also ensure the normal operation of the economy and the market competition vitality. Actually they plays an important part to promote our country's employment.

Specifically, small and medium-sized enterprises fully participate in the market economy. Its economic diversity means the internal requirement of market economy. Their flexible production and mechanism greatly save the production cost, reduce risk, and increase the profits. The characteristics of their quick investment and labor-intensive industries have attracted a lot of people to be employed. As a developing country with a large population, China's the low level of industrialization can be improved by small and medium-sized enterprises, in the way of improving and optimizing the structure of employment. In addition, small and medium-sized enterprises promote rural economic development, which is conducive to increasing local revenue. According to some statistics, small and medium-sized enterprises have absorbed labor force of about 230 million since 1978, and vigorously promoted the urbanization process of rural areas in China. [1] What's more, small and medium enterprises have promoted technological innovation in our country. Based on the characteristics of labor-intensive and capital-intensive operation of small and medium-sized enterprises, the science and technology has greatly developed from theory to application. According to some statistics, $76 \%$ of the 94 technology advanced enterprises in Shenzhen are small and medium-sized enterprises, and the proportion of small and medium-sized enterprises is as high as 90\% among 124 high-tech enterprises. [2]The development of small and medium-sized enterprises in China has long been plagued by capital shortage, especially since the outbreak of the global financial crisis in 2008. Great changes have taken place in small and medium-sized enterprise's survival environment and the financing difficult problem is especially prominent. [3]

Credit risk characteristics of small and medium-sized enterprises in China. First of all, with a low threshold, the competition among the small and medium-sized enterprises in China is so fierce that they are at a disadvantage in the competition with large enterprises. Most of the small and medium-sized enterprises are prone to risk investment in other industries, and the cash flows generated by operating activities are mainly used to repay bank loans, usually resulting in the failure of capital chain. From the perspective of the bank, small and medium-sized enterprises are easy to 
misappropriate liquid capital loans for fixed-asset construction. Secondly, the lack of a sound professional manager team and internal management mechanism may bring the results that the small and medium-sized enterprise management decision-making depends largely on the actual controllers. However, the actual controllers tend to lose their original passion gradually and the poor management ability may have a negative impact on the enterprise's development in the future.

\section{Causes and Identification of Credit Risks of Small and Medium-sized Enterprises in China}

Small and medium-sized enterprise credit risks mainly have the following three characteristics: the first one is uncertainty. With the basic uncertainty of the risk itself, the operating ability, moral level and management ability of both sides all add to the degree of uncertainty; the second characteristic is the transmission. The credit risk of the transaction of both parties is likely to lead to the credit risk of the third party, thus forming the credit risk chain. The third is the accumulation, when the credit risk spreads rapidly in a trading system, the sum of credit risk is easy to grow rapidly.

The identification of credit risk of small and medium-sized enterprises in China can be divided into two categories, the general and specific type of customer risk. Due to the fact that the small and medium-sized enterprises are mainly private enterprises, they are greatly influenced by national macro policies and industry cycle fluctuations. In terms of tax avoidance, financial operation is often not authentic, thus banks cannot obtain true information to make correct judgments on the financial situation of enterprises. In terms of such common risks, the bank should take the responsibility to do survey on enterprises through various channels in order for all-round information of the enterprise. At the same time, the Bank should attach importance to non-financial indicators to obtain the information of real development level and growth background of enterprises, such as whether it has participated in private lending. [4]

There are three types of customer risks for a specific type: the first is equity risk. Banks can take parent company as the starting point and attract other high-quality members into the bank customer base. What's more, they can choose the enterprises that have the scale advantage, high-management level, high-position in its industry. Also, the Bank should be careful of the enterprises which has complex equity, opaque information or bad credit records. The second type is supply-chain risk. According to the supply chain upstream and downstream enterprises as well as management and control factors, such as trading, banks should carefully consider whether the core management system is in concert with the enterprise. It's also of vitally importance for the bank to choose enterprises with high-management level and comprehensive strength. In addition, based on the risk of credit concentration in a single supply chain, the bank should determine the total amount of credit in terms of the annual supply chain transaction volume. The last type is the industry-park risk. National and provincial parks have strong development momentum, in terms of which banks could determine its cooperating partner. Before they carry out their cooperation, the bank should seek thorough information to ensure the park development situation, including the position of enterprises in the industrial chain link and the relative competitive advantage. Having taken all the superiority and inferiority into consideration, the bank could finally form the target customer list.

\section{Countermeasures of Credit Risk Management for Small and Medium-sized Enterprises}

Strengthen state support for ' fiscal and tax measures. First of all, the state should be aimed at the financing problem of and increasing the intensity of the rewards for banks, thus encouraging banks to lend to small and medium enterprises. Relevant authorities could set up small and-medium-enterprise development fund, to enable small and medium-sized enterprises to develop new technologies and provide risk compensation. Low-interest and interest-free loans help small and medium-sized enterprise purchase basic facilities and the means of production. In addition, the state should reduce the tax expenses of small and medium-sized enterprises and increase the enforcement of supervision. [5] Based on the characteristics of the enterprise and the profitability of the company, the state could establish credit risk compensation mechanism for small and 
medium-sized enterprises to make up for the credit risk caused by natural disasters. For banks, appropriate subsidies should be given to the interest on loans that cannot be recovered before the deadline.

Construction of credit guarantee mechanism. From commercial Bank' view, the first source of repayment of small and medium-sized enterprises plays a key role. For one thing, commercial Bank should spare no effort to promote the effective credit guarantee mechanism to avoid risks. There are many problems in the guarantee management system in China, such as the lack of system, the lack of judgment on the guarantee ability, the support and use of the evaluation of the value of the market, as well as the lack of big data. Bank should strengthen their management of collateral. For another thing, there are serial guarantee in the guarantee circle, and the government debt has forced the debt of the bank to continue lending. On this issue, Bank should guarantee financing customers and develop a compression plan for the operation of enterprises. At the same time, the supplemental shareholder personal guarantee should be improved and the promotion of the third party supervision of the liquid assets as an anti-guarantee should be developed. [6]

Improve the construction of the financial environment and conditions of small and medium-sized enterprises. First of all, we could establish and improve the credit guarantee mechanism of small and medium-sized enterprises, and add third-party institutions to provide assistance and support for the technology development, export commodities and equipment replacement. Relevant departments should also launch a policy on the credit guarantee system of small and medium-sized enterprises as soon as possible. In addition, banks should learn from the successful experience of foreign countries and use advanced technology and innovative experiment to break through business innovation and improve the applicability of financial services. In particular, banks can design light-asset credit products for the light-asset characteristics of technology enterprises. The most important characteristic of technology-oriented small and medium-sized enterprises is the light assets and the lack of traditional collateral, which is the reason why it's always difficult for banks to serve. On the basis of the improvement of risk control ability, commercial banks could gradually increase their recognition of enterprises' intellectual property rights and equity, and develop products of intellectual property rights pledge and equity pledge loan. [7]

Improve the financing capacity of small and medium-sized enterprises. According to the requirements of modern enterprise system we could improve the governance and management structure of small and medium-sized enterprises. In terms of different industries, relevant authorities could provide professional guidance in particular for small and medium-sized enterprises, and work out specific solutions of characteristic problem of each enterprise. On the basis of this, we could assist small and medium-sized enterprises develop in industrial clusters and break down the solidification regulations in telecommunications, power, finance and other industries. In addition, it' also significant to help medium and small businesses change the traditional management mechanism and add more elements of innovation, technological transformation of enterprises instead. Certain rules and regulations should be set up for these enterprises to abide by thus to improve the credit consciousness and make correct financial behavior a reality.

\section{Conclusion}

In the past-crisis era, the credit risk management of small and medium-sized enterprises in China's commercial banks faces great challenges. Through the above summary, only with full consideration can our country's small and medium-sized enterprises own unique operating characteristics and promote the development of credit business of commercial banks as well as the speed of progress on the basis of reality. At the same time, commercial banks need to have a comprehensive understanding of industry, area, credit management level and other factors, thus to formulate specific corresponding credit strategy and timely adjustment. Only in this way can we truly achieve the goal of strategic transformation of commercial banks in our country. 


\section{References}

[1] Z. Meng, H.B. Hu. Research on the influence mechanism of small and medium-sized enterprise loan pricing in commercial Banks based on credit risk assessment [J]. International business (journal of foreign economic and trade university), 2014, (05):43-52.

[2]R. Huang. A study on credit risk assessment of small and medium enterprises in commercial Bank [D]. Jiangsu University, 2009.

[3] L. Wang. Risk prevention research on the credit business of small and medium enterprises in commercial Bank [J]. New finance, 2011, (01): 53-54.

[4] Y. Xu. Analysis and countermeasures of credit risk of small and medium-sized enterprises in commercial Bank in China [D]. Anhui University, 2013.

[5]C.H. Jiang. Analysis of credit risk and management of small and medium enterprises in commercial Bank [D]. Jiangxi University of finance and economics, 2006.

[6] M.Q. Wang. Analysis and countermeasures of credit risk of small and medium enterprises in commercial Bank in China [D]. Zhejiang University, 2015.

[7] T. Yin, X.W. Wang, Y.Y. Du. Research on the structural reform of technology and financial supply of commercial Bank -- the perspective of risk income structure [J]. New finance, 2016, (08): 28-31. 